Journal of Agricultural Sciences
(Tarim Bilimleri Dergisi)

\title{
Effects of Phytase Enzyme Supplementation to Hazelnut Meal Based Diets on Growth Performance and Nutrient Digestibility of Siberian sturgeon (Acipenser baerii Brand, 1869)
}

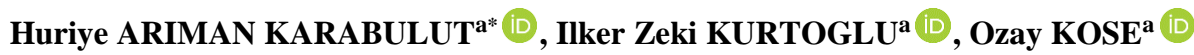 \\ ${ }^{a}$ Department of Aquaculture, Faculty of Fisheries, Recep Tayyip Erdogan University, Rize, 53100, TURKEY \\ ARTICLE INFO \\ Research Article \\ Corresponding Author: Huriye ARIMAN KARABULUT, E-mail: huriye.ariman@erdogan.edu.tr \\ Received: 23 December 2019 /Revised: 21 February 2020 / Accepted: 11 March 2020 / Online: 31 May 2021
}

\section{ABSTRACT}

This research was carried out to determine that the effects of diets containing $30 \%$ hazelnut meal and different proportions of phytase enzymes on the growth performance of Siberian sturgeon (Acipenser baerii) (initial mean weight, $960.23 \pm 0.55 \mathrm{~g}$ ). The trial diets consisted of feeds supplemented with $0.25 \mathrm{~g} \mathrm{~kg}^{-1}$ (G2), $0.50 \mathrm{~g} \mathrm{~kg}^{-1}$ (G3), and $1.00 \mathrm{~g}$ $\mathrm{kg}^{-1}$ (G4) phytase enzyme, and with no enzyme added to the control group (G1), respectively. Experiment groups were performed in 3 replicates and trials were carried out for 90 days.
As a result, adding phytase enzyme to feeds contain $30 \%$ hazelnut meal was found to have a positive effect on the weight gain (WG, g), the protein efficiency ratio (PER), feed conversion ratio (FCR), and specific growth rate (SGR, \%). Growth performance was found to be more successful in all groups fed feeds supplemented with phytase enzyme compared to the $\mathrm{G} 1$ group $(\mathrm{P}<0.05)$. The $\mathrm{G} 4$ was the best group than the others statistically $(\mathrm{P}<0.05)$. In terms of the digestibility effect of enzyme added groups, the highest total digestion rate $(77.14 \pm 0.07 \%)$ was obtained in the G4 enzyme group and the lowest total digestibility (74.32 $\pm 0.02 \%$ ) was estimated in the $\mathrm{G} 1$.

Keywords: Phytase; Plant protein; Sturgeon; Acipenser baerii; Fish meal

Ankara University, Faculty of Agriculture

\section{Introduction}

The feed costs constitute 50-75\% of total operational expenses in aquaculture. The high protein-containing raw materials are used in feed production and fish meal is preferred. In recent years, the increase in fish meal prices has escalated feed costs (Akiyama 1995). The fish meal and fish oil import reached up to 123 thousand tons and 40 thousand tons as of 2017 in Turkey. The amount of foreign currency paid for fish meal import is 155 million dollars (Anonymous 2017). The plant-based feed raw materials are shown as a remedy for reducing feed costs (Akiyama 1995). Many studies have been carried out regarding the use of plant-based feed ingredients instead of some or all of the fish meal. In these studies, with the increased protein qualities of legumes and oilseed meal, the negative effects were addressed and the insufficient amino acid structure was tried to be balanced by the addition of various synthetic amino acids and various attractant substances to increase feed intake (Yeşilayer et al. 2013; Morales et al. 2016; Jiang et al. 2018; Arıman Karabulut et al. 2019). During the past two decades, the use of enzymes to reduce the adverse effects of anti-nutritional factors arising from feed additives, to increase feed digestibility, and to reduce environmental impacts is becoming increasingly widespread in animal production (Cao et al. 2007; Zhu et al. 2014; MirelesArriaga et al. 2015). The phytic acid content of the plant originated raw materialsis different. For example, it ranges between 0.50 and $1.89 \%$ in wheat, 0.40 and $2.06 \%$ in legumes, 2.00 and $5.20 \%$ in oilseed plant, 1.00 and $2.20 \%$ in soybean, and 0.23 and $0.92 \%$ in hazelnut (Schlemmer et al. 2009).

In-plant feed ingredients, the amount of phosphorus is sufficient for fish metabolism. However, owing to the presence of phosphorus phytin in soybean meal and by-products, its digestibility is low (Wang et al. 2009). The effectiveness of the fish to benefit from phosphorus can be increased by the soybean meal, which is subjected to pre-treatment with phytase enzyme. It has been reported that the use of phytase enzyme reduces the excretion of phosphorus in aquaculture. Phytase is the enzyme that removes phosphates from the structure of phytic acid by providing hydrolysis (Selle et al. 2000; Zhu et al. 2014; von Danwitz et al. 2016).

The using rate of enzymes at the feed 1-2\%o will have a minor effect on the feed cost. However, positive effects such as improving the digestibility of feeds, increasing feed utilization rate and creating less phosphorus excretion to the environment cover this cost excessively. Commercial enzymes are still used today in poultry feeds. The use of enzymes produced for fish feed is relatively new in the market (Yiğit \& Koca 2011). It has been used more and more in fish feeds for the last two decades 
to make better use of plant nutritional supplements. The addition of protease, mixed enzyme, and phytase to sea bream feed using soybean meal instead of fish meal (40\% soybean meal, $25 \%$ fish meal) resulted in significantly better feed evaluation (Ayhan et al. 2008). Farhangi \& Carter (2007) reported that in the feed of rainbow trout, which is $16.58 \mathrm{~g}$, the addition of different exogenous enzymes increases the use of plant additives and reaches a better feed conversion ratio (FCR) value than fish meal supplemented feed group. Wang et al. (2009) added different levels of phytase to the feed of Oncorhynchus mykiss with soybean meal and determined that the phytase enzyme increased the digestibility of proteins and minerals, decreased the digestion of fats, and also decreased the loss of nutrients by feces. In another study, it has been determined that the addition of multienzyme to the plant additives feed of juvenile Huso huso significantly improved weight and increased the SGR and FCR (Ghomi et al. 2012).

The literature on the use of phytase in the feed of sturgeon is limited but the phytase enzyme additive feeds are investigated in Oncorhynchus mykiss (Wang et al. 2009; Morales et al. 2016), Oreochromis niloticus x Oreochromis aureus (Lin et al. 2007), Pelteobagrus fulvidraco (Zhu et al. 2014), Psetta maxima (von Danwitz et al. 2016), Ictalurus punctatus (Chen et al. 2019) and Pagrus major (Biswas et al. 2019).

Sturgeon is a species with a high economic and ecological value, because of the meat and its caviar in terms of aquaculture (Arıman Karabulut \& Osmanoglu 2019). In this study, the effect of the use of phytase enzyme with different levels of hazelnut meal that is added to Siberian sturgeon (Acipenser baerii) feed was conducted.

\section{Material and Methods}

\subsection{Rearing and facilities}

This research was conducted at Recep Tayyip Erdogan University (RTEU) Aquaculture Application and Research Center between December 2018 and March 2019 (90 days) under natural photoperiod conditions. In total, 120 randomly sampled Siberian sturgeon $(960.23 \pm 0.55 \mathrm{~g})$ were used at $1^{+}$years of age. Fishes were placed in 12 tanks with a tank volume of $605 \mathrm{~L}$ (water level adjusted to $480 \mathrm{~L}$ ), with 10 fish in each tank. During the study, the development of fish was monitored by individual length and weight measurements at 15-day intervals. Water temperature, dissolved oxygen, and $\mathrm{pH}$ values were routinely measured throughout the experiment. The temperature, $\mathrm{pH}$ and oxygen minimum and maximum values were determined between 9.5 and $13.5^{\circ} \mathrm{C}, 7.1$ and 7.4, and 9.8 and $9.9 \mathrm{mg} \mathrm{L}^{-1}$, respectively.

\subsection{Experimental diets}

The feeds with $45 \%$ crude protein (isonitrogenous) and $12.7 \%$ crude lipid used in the experiment were produced with fish meal, hazelnut meal, boncalite, corn gluten, fish oil, pellet binder, vitamin-mineral mixes, and different ratios of phytase enzyme $(0.25$ $\mathrm{g} \mathrm{kg}^{-1} ; \mathrm{G} 2,0.50 \mathrm{~g} \mathrm{~kg}^{-1} ; \mathrm{G} 3$ and $\left.1.00 \mathrm{~g} \mathrm{~kg}^{-1} ; \mathrm{G} 4\right)$. Fish meal, fish oil, hazelnut meal, corn gluten, boncalite, vitamins-mineral mixes were obtained from a commercial feed factory (KAGSAN-Trabzon-Turkey). Similarly, 6-phytase (E.C.3.1.3.26) enzyme (Ronozyme HiPhos (M) produced by the strain Aspergillus oryzae DSM 22594) was obtained from DSM Nutritional Products in Istanbul Turkey.

The basic nutritional content of feed ingredients (crude protein (CP), dry matter (DM), crude ash (CA), crude lipid (CL), nitrogen-free extracts (NFE), and crude cellulose) was analyzed in the RTEU Faculty of Fisheries laboratories. The formulation of feeds was calculated using the Microsoft Office Excel program.

The four different feeds, which are control (G1), G2, G3, G4, and contain phytase enzyme $0,0.25,0.50, \mathrm{and}^{1.00 \mathrm{~g} \mathrm{~kg}}{ }^{-1}$, respectively, were prepared (Table 1). First, the feed raw materials were milled and sieved through a $500 \mu \mathrm{m}$ mesh screen and mixed for 15 minutes until a homogeneous mixture was obtained. Then, phytase enzyme (except G1), fish oil, and 35\% distilled water were added and mixed for 15 minutes, and pulped. The dough mixture was passed through a mincing machine and pellets suitable for fish were created. The prepared pellets were dried in the POL-EKO APARATURA brand drying cabinet set at 50 ${ }^{\circ} \mathrm{C}$ for 24 hours (Gimenez et al. 2009). The feeds taken from the oven were kept at normal room temperature and cooled, then stored at $-20{ }^{\circ} \mathrm{C}$ to prevent enzyme degradation. 
Table 1- Ingredients and proximate composition of experimental diets (\% dry matter)

\begin{tabular}{|c|c|c|c|c|}
\hline Ingredients & $G 1$ & $G 2$ & G3 & G4 \\
\hline Fishmeal & 30 & 30 & 30 & 30 \\
\hline Hazelnut meal (defatted) & 30 & 30 & 30 & 30 \\
\hline Boncalite & 12 & 11.75 & 11.5 & 11 \\
\hline Corn gluten & 16 & 16 & 16 & 16 \\
\hline Fish oil & 8.25 & 8.25 & 8.25 & 8.25 \\
\hline Phytase & 0 & 0.25 & 0.5 & 1 \\
\hline Methionine & 0.5 & 0.5 & 0.5 & 0.5 \\
\hline Lysine & 0.5 & 0.5 & 0.5 & 0.5 \\
\hline Vitamin mixture & 0.75 & 0.75 & 0.75 & 0.75 \\
\hline Mineral mixture & 0.5 & 0.5 & 0.5 & 0.5 \\
\hline Molasses & 1 & 1 & 1 & 1 \\
\hline Chromic oxide $\left(\mathrm{Cr}_{2} \mathrm{O}_{3}\right)$ & 0.5 & 0.5 & 0.5 & 0.5 \\
\hline \multicolumn{5}{|l|}{ Proximate composition } \\
\hline Dry matter (DM) (\%) & 91.3 & 90.8 & 91.1 & 91.0 \\
\hline Crude protein $(\mathrm{CP})(\%)$ & 45.10 & 45.12 & 45.14 & 45.19 \\
\hline Crude lipid (CL) (\%) & 12.69 & 12.68 & 12.68 & 12.67 \\
\hline Crude ash (CA) (\%) & 8.1 & 8.2 & 8.1 & 8.0 \\
\hline Crude cellulose (CC) (\%) & 2.10 & 2.08 & 1.99 & 2.00 \\
\hline NFE & 23.31 & 22.01 & 23.18 & 23.14 \\
\hline $\mathrm{GE}\left(\mathrm{MJ} \mathrm{kg}^{-1}\right)$ & 19.74 & 19.72 & 19.73 & 19.69 \\
\hline
\end{tabular}

Note: Vitamin mixture: Included of per kg; Vitamin A 20.000.000 IU, Vitamin $\mathrm{D}_{3} 2.000 .000 \mathrm{IU}$, Vitamin E $200.000 \mathrm{mg}$, Vitamin $\mathrm{K}_{3} 12.000 \mathrm{mg}$, Vitamin B $20.000 \mathrm{mg}$, Vitamin B $30.000 \mathrm{mg}$, Vitamin B $20.000 \mathrm{mg}$, Vitamin B $1250 \mathrm{mg}$, Vitamin C 200.000 mg, Niacin 200.000 mg, Cal.D. Panth. 50.000 mg, Folic acid 6.000 mg, D-Biotin $500 \mathrm{mg}$, Cholin Chloride $300.000 \mathrm{mg}$; Mineral mixture: Included of per kg; $60 \mathrm{mg}$ Manganese, $80 \mathrm{mg}$ Zinc, $60 \mathrm{mg}$ Ferro, $5.000 \mathrm{mg}$ Copper, $2.000 \mathrm{mg}$ Iodine, $1.000 \mathrm{mg}$ Cobalt, $200 \mathrm{mg}$ Selenium, $50 \mathrm{mg}$ Magnesium. Nitrogen free extracts (NFE) = matter $-(\mathrm{CP}+\mathrm{CL}+\mathrm{CA})($ adapted by Liu et al. 2009) Gross energy $(\mathrm{GE})=$ $\left(\mathrm{CP} \times 23.9 \mathrm{MJ} \mathrm{kg}^{-1}\right)+\left(\mathrm{CL} \times 39.8 \mathrm{MJ} \mathrm{kg}^{-1}\right)+\left(\mathrm{NFE} \times \mathrm{CC} \times 17.6 \mathrm{MJ} \mathrm{kg}^{-1}\right)($ adapted by von Danwitz et al. 2016).

\subsection{Feeding and feces collection}

The feeds were prepared as $2 \%$ of the bodyweight after measurements were recorded every 15 days. Feeding was carried out by hand three times a day, 9:00 am, 1:00 pm, and 5:00 pm equal to each meal. After one hour from feeding, the fecal collection was performed by siphoning method (Liu et al. 2009). The collected samples of feces were frozen at $-20{ }^{\circ} \mathrm{C}$ without waiting and stored in the freezer until analysis was performed (Adapted by Omnes et al. 2017).

\subsection{Determination of apparent digestibility coefficient}

After three months of the experiment, $0.5 \%$ ratio chromium oxide $\left(\mathrm{Cr}_{2} \mathrm{O}_{3}\right)$ was added as an indicator to calculate the digestion rates of the nutrients in the trial feeds. To determine the digestion rates in the groups, the fish were adapted to indicator supplemented feeds for 5 days. Following the adaptation process, feces were collected from the tanks with siphoning. Apparent digestibility coefficients for dietary nutrients were calculated as follows:

ADC of nutrient $(\%)=100 \times\left[1-\left(\mathrm{Cr}_{2} \mathrm{O}_{3}\right.\right.$ in diet $/ \mathrm{Cr}_{2} \mathrm{O}_{3}$ in faeces $) \times$ (nutrient in faeces/nutrient in diet) $]$

$\operatorname{ADC}$ of dry matter $(\%)=100 \times\left[1-\left(\mathrm{Cr}_{2} \mathrm{O}_{3}\right.\right.$ in diet $/ \mathrm{Cr}_{2} \mathrm{O}_{3}$ in faeces $\left.)\right]$ (Jiang et al. 2018).

\subsection{Sample collection and chemical analyses}

Both at the beginning and the end of the experiment, 3 specimens were taken randomly from each tank and their length and weights were determined. The samples were humanely killed by overdose anesthesia (100 ppm clove oil) based on the procedures of the Recep Tayyip Erdogan University Ethics Committee (Decision No: 2015/17). The carcass weights were determined by 
removing the head, fins and internal organs of the fish. (adapted by Jiang et al. 2018). The fish meat composition was defined by the analysis of CP, CL, CA, moisture (M), and DM. The DM ratio of the fish meats was calculated according to "TS 1743 $\left(110 \pm 1{ }^{\circ} \mathrm{C}\right)$ ", CP according to the "Kjeldahl Method", CL according to the "Soxhlet Method" (Lovell 1981), CA according to "TS 1746" (550 $\left.\pm 1{ }^{\circ} \mathrm{C}\right)$ " (Lovell 1981; AOAC 2000). The amino acid analysis of the trial feeds was performed by Kazlıçeşme $\mathrm{R} \& \mathrm{D}$ Laboratory and the results were presented in Table 2. The nutritional ratios of experimental feed and feces were determined with respect to AOAC (2000). The chromium oxide ratios in feed and feces samples were determined with respect to Furukawa \& Tsukahara (1966).

Table 2- Amino acid content of experimental diets (\% of dietary protein)

\begin{tabular}{lllll}
\hline Essential amino acids & $G 1$ & $G 2$ & $G 3$ & $G 4$ \\
\hline Valine & 4.47 & 4.45 & 4.46 & 4.45 \\
Leucine & 4.60 & 4.63 & 4.61 & 4.61 \\
Isoleucine & 3.09 & 3.10 & 3.11 & 3.10 \\
Lysine & 7.65 & 7.64 & 7.66 & 7.67 \\
Phenylalanine & 5.09 & 5.10 & 5.12 & 5.11 \\
Threonine & 3.90 & 3.89 & 3.92 & 3.86 \\
Histidine & 3.55 & 3.55 & 3.54 & 3.53 \\
Methionine & 2.68 & 2.71 & 2.70 & 2.70 \\
Arginine & 5.70 & 5.73 & 5.79 & 5.67 \\
\hline Non-essential amino acids & & & & \\
\hline Alanin & 2.63 & 2.60 & 2.64 & 2.64 \\
Aspartik Acid & 4.42 & 4.46 & 4.48 & 4.47 \\
Tyrocine & 1.32 & 1.30 & 1.33 & 2.30 \\
Gylcine & 2.31 & 2.29 & 2.30 & 2.43 \\
Proline & 2.40 & 2.39 & 2.41 & 0.29 \\
Cystine & 0.29 & 0.30 & 0.31 & 6.13 \\
Glutamic Acid & 6.11 & 6.10 & 6.12 & 2.03 \\
Serine & 2.02 & 1.99 & 2.04 & \\
\hline
\end{tabular}

\subsection{Statistical analysis}

Results are presented as determined by the mean $\pm \mathrm{SE}$ of three replicates. To evaluate the findings of the present study Sigma Plot 11.0 package programs were used. All data were subjected to one-way analysis of variance (ANOVA) and then by TUKEY's multiple range test. it was considered significant with a p-value of $<0.05$.

\section{Results}

\subsection{Feed utilization and growth performance}

At the end of the study, the growth performance data of fish fed with different amounts of enzyme-containing feed for 90 days are presented in Table 3. According to these data, the best specific growth rate (SGR) and weight gain (WG) were observed in the G4 group. The G4 group was followed by G3, G2, and G1, respectively, and the differences between all groups were found to be statistically significant $(\mathrm{P}<0.05)$. While the best FCR was found in the G4 group, the worst FCR was obtained in the G1 group. The best protein efficiency ratio (PER) was found in G4 between all groups. While the difference between all groups was statistically significant in terms of PER, there was no difference in terms of condition factor $(\mathrm{CF})(\mathrm{P}<0.05)$.

Table 3- Effect of dietary enzyme supplementation on the performance of Siberian sturgeon

\begin{tabular}{lllll}
\hline Parameters & G1 & G2 & G3 & \multicolumn{1}{c}{ G4 } \\
\hline IBW (g) & $961.27 \pm 4.21$ & $958.73 \pm 1.60$ & $959.97 \pm 3.43$ & $960.96 \pm 9.27$ \\
FBW (g) & $1119.58 \pm 2.61^{\mathrm{a}}$ & $1273.93 \pm 4.33^{\mathrm{b}}$ & $1370.65 \pm 3.21^{\mathrm{c}}$ & $1433.18 \pm 1.85^{\mathrm{d}}$ \\
WG $(\mathrm{g})$ & $158.33 \pm 1.51^{\mathrm{a}}$ & $315.21 \pm 1.28^{\mathrm{b}}$ & $410.70 \pm 1.74^{\mathrm{c}}$ & $472.23 \pm 0.68^{\mathrm{d}}$ \\
WGR (\%) & $16.45 \pm 2.05^{\mathrm{a}}$ & $32.92 \pm 1.89^{\mathrm{b}}$ & $42.77^{\mathrm{a}} \pm 1.09^{\mathrm{c}}$ & $49.35^{\mathrm{a}} \pm 2.11^{\mathrm{d}}$ \\
SGR $(\%)$ & $0.17 \pm 0.24^{\mathrm{a}}$ & $0.33 \pm 0.16^{\mathrm{b}}$ & $0.41 \pm 0.17^{\mathrm{c}}$ & $0.46 \pm 0.15^{\mathrm{cd}}$ \\
FCR & $1.98 \pm 0.10^{\mathrm{a}}$ & $1.60 \pm 0.03^{\mathrm{b}}$ & $1.52 \pm 0.05^{\mathrm{c}}$ & $1.41 \pm 0.03^{\mathrm{d}}$ \\
FI $\left(\%\right.$ day $\left.^{-1}\right)$ & $313.49 \pm 2.07$ & $504.34 \pm 0.25$ & $624.26 \pm 1.38$ & $665.85 \pm 1.21$ \\
PER & $3.52 \pm 0.34^{\mathrm{a}}$ & $6.98 \pm 0.29^{\mathrm{b}}$ & $9.11 \pm 0.31^{\mathrm{c}}$ & $10.43 \pm 0.22^{\mathrm{d}}$ \\
CF $(\%)$ & $0.35 \pm 0.02^{\mathrm{a}}$ & $0.38 \pm 0.01^{\mathrm{a}}$ & $0.42 \pm 0.04^{\mathrm{ab}}$ & $0.45 \pm 0.04^{\mathrm{ab}}$ \\
\hline
\end{tabular}

Note: Data represent as mean $\pm S E$ of triplicate tanks $(n=10, r=3)$; mean values in the same row with different superscripts are significantly different $(\mathrm{P}<0.05)$. IBW: Initial body weight; FBW: Final body weight; DBW: Deat body mass; " $\mathrm{t}$ " is the number of culture days. Weight gain $(\mathrm{WG}$, g) = FBW-IBW Weight gain rate $(\mathrm{WGR})=100 \times[(\mathrm{FBW}-\mathrm{IBW}) / \mathrm{IBW}]$, Specific growth rate $(\mathrm{SGR}, \% /$ day $)=100 \times[(\mathrm{ln} \mathrm{FBW}-\mathrm{ln} \mathrm{IBW}) / \mathrm{t}], \mathrm{Feed}$ conversion ratio $(\mathrm{FCR})=$ $[($ feed consumed $) /($ wet weight gain $)]$, Feed intake $($ FI, \%/day $)=100 \times($ dry feed intake $) /[($ IBW + FBW + DBW $) / 2 \times t)]$, Protein efficiency ratio $($ PER $)=$ wet weight gain / protein intake, Condition factor $(\mathrm{CF})=($ wet weight $/$ total length $\mathrm{cm} 3) \times 100$ 


\subsection{Apparent digestibility coefficients}

The digestibility values of the nutrients in the groups fed with the experimental feeds are presented in Table 4 . The best total digestion rate and protein digestion rate were obtained at the $\mathrm{G} 4$ group. As a result of the study, total digestion rate, protein digestion rate, and lipid digestion rate values were found to be statistically significant in the experimental groups to the G1 group $(\mathrm{P}<0.05)$.

Table 4- Effect of dietary enzyme supplementation on the apparent digestibility coefficient (ADC) of Siberian sturgeon

\begin{tabular}{lrrrr}
\hline$A D C(\%)$ & $G 1$ & $G 2$ & $G 3$ & $G 4$ \\
\hline Dry matter & $74.32 \pm 0.02^{\mathrm{a}}$ & $74.98 \pm 0.10^{\mathrm{b}}$ & $76.05 \pm 0.12^{\mathrm{c}}$ & $77.14 \pm 0.07^{\mathrm{d}}$ \\
Protein & $81.27 \pm 0.27^{\mathrm{a}}$ & $82.77 \pm 0.11^{\mathrm{b}}$ & $84.89 \pm 0.09^{\mathrm{c}}$ & $85.03 \pm 0.12^{\mathrm{d}}$ \\
Lipid & $83.39 \pm 0.16^{\mathrm{a}}$ & $85.80 \pm 0.09^{\mathrm{b}}$ & $86.06 \pm 0.03^{\mathrm{b}}$ & $90.44 \pm 0.14^{\mathrm{c}}$ \\
\hline
\end{tabular}

Note: Data represent as mean $\pm S E$. Mean values in the same row with different superscripts are significantly different $(\mathrm{P}<0.05)$

\subsection{Whole-body index and body composition}

The Viscerosomatic index (VSI), Gonadosomatic index (GSI), and Hepatosomatic index (his) values got at the end of the experiment are given in Table 5. In terms of hepatosomatic organs and gonadosomatic organs, the experimental groups were found to have a lower value than the G1 group as well as the digestive performance. The gonad weights of the enzyme-added groups were observed heavier than the G1 group and the difference between the groups was statistically significant $(\mathrm{P}<0.05)$.

Table 5- Body composition and biometric parameters at the end of the experiment

\begin{tabular}{lllll}
\hline Parameters & $G 1$ & $G 2$ & $G 3$ & $G 4$ \\
\hline HSI (\%) & $5.29 \pm 0.42^{\mathrm{a}}$ & $3.80 \pm 0.25^{\mathrm{b}}$ & $3.72 \pm 0.23^{\mathrm{b}}$ & $12.01 \pm 1.16^{\mathrm{b}}$ \\
VSI (\%) & $14.3 \pm 2.02^{\mathrm{a}}$ & $12.18 \pm 1.53^{\mathrm{b}}$ & $0.52 \pm 0.84^{\mathrm{b}}$ & $11.4 \pm 0.94^{\mathrm{c}}$ \\
GSI (\%) & $0.18 \pm 0.13^{\mathrm{a}}$ & $0.47 \pm 1.10^{\mathrm{a}}$ & $25.02 \pm 0.01^{\mathrm{c}}$ & $0.58 \pm 0.03^{\mathrm{b}}$ \\
Crude matter (CM) (\%) & $23.04 \pm 0.01^{\mathrm{a}}$ & $24.88 \pm 0.02^{\mathrm{b}}$ & $25.37 \pm 0.03^{\mathrm{c}}$ \\
Crude protein (CP) (\%) & $17.53 \pm 0.10^{\mathrm{a}}$ & $18.44 \pm 0.13^{\mathrm{b}}$ & $18.57 \pm 0.19^{\mathrm{b}}$ & $18.92 \pm 0.22^{\mathrm{c}}$ \\
Crude lipid (CL) (\%) & $2.69 \pm 0.22^{\mathrm{a}}$ & $2.58 \pm 0.10^{\mathrm{b}}$ & $2.56 \pm 0.31^{\mathrm{b}}$ & $2.57 \pm 0.07^{\mathrm{b}}$ \\
Crude ash (CA) (\%) & $0.82 \pm 0.11^{\mathrm{a}}$ & $0.77 \pm 0.10^{\mathrm{b}}$ & $0.76 \pm 0.22^{\mathrm{b}}$ & $0.76 \pm 0.14^{\mathrm{b}}$ \\
\hline
\end{tabular}

Note: Data represent as Mean $\pm S E$ of triplicate tanks $(\mathrm{n}=3, \mathrm{r}=3)$; mean values in the same row with different superscripts are significantly different $(\mathrm{P}<0.05)$. Hepatosomatic index (HSI) $(\%)=100 \times($ liver weight $(\mathrm{g}) /$ fish weight $(\mathrm{g}))$, Viscerosomatic index $(\mathrm{VSI})(\%)=100 \times(\mathrm{viscera}$ weight $(\mathrm{g}) / \mathrm{whole}$ body weight $(\mathrm{g}))$, Gonadosomatic index $(\mathrm{GSI})(\%)=100 \times(\mathrm{gonad}$ weight $(\mathrm{g}) /$ whole body weight $(\mathrm{g}))$

\section{Discussion}

In this research, the potential of phytase enzyme supplemented and hazelnut meal added fish feed in Siberian sturgeon cultivation and its effects on fish growth parameters were investigated.

In some studies, it has been reported that the use of multienzyme and phytase enzyme in omnivorous and herbivorous fed warm-water fish feeds, which can benefit better from plant feed raw materials, achieved successful results (Lin et al. 2007; Chen et al. 2019). Yan et al. (2002) fed channel catfish (Ictalurus punctatus), which weighed $12 \mathrm{~g}$, with a phytase-supplementary fish feed. They reported that enzyme-supplemented feed did not affect weight gain, however, feed intake was higher in the control group than in the phytase groups. Lin et al. (2007), the commercial enzyme complex supplemented with soybean and cotton meal containing fish feeds was used and they fed hybrid tilapia (Oreochromis niloticus) which weighed $18 \mathrm{~g}$. As a result, they reported that the enzyme-containing groups observed better growth performance than the control group. Chen et al. (2019) investigated the nutrient utilization, growth performance, and phosphorus equivalence in the usage of phytase in plant-based feeds on channel catfish (I. punctatus). As a result, they reported that the growth performance of phytase, which is complementary to fish feed, the FCR, the digestibility coefficient of phosphorous increased, and phosphorus content excreted in feces decreased significantly. Ghomi et al. (2012) used multienzyme supplementary feed (250 $\left.\mathrm{mg} \mathrm{kg}^{-1}\right)$ at fingerling Huso huso with an initial weight of $9.76 \pm 0.68 \mathrm{~g}$. As a result of exogenous enzyme addition higher WG $(53.03 \pm 0.15 \mathrm{~g})$, the best SGR (3.68 $\pm 0.17 \%)$, and the best FCR $(3.49 \pm 0.14)$ were found. The same researchers reported that enzyme addition provided significant improvement in comparison with the control group. Ávila et al. (2015) used soybean meal as the main protein source in the juvenile rainbow trout diet and investigated its effects on growth performance, phosphorus excretion, and lysozyme activity by supplementation yeast and phytase enzyme to the diet. As a result of the study, higher values were observed on the SGR, FCR, and Protein conversion ratio (PCR) on the groups fed with yeast and phytase enzyme supplemented diets than those observed in 
the commercial diet, but no significant differences were reported. Wang et al. (2009) have fed rainbow trout for 90 days with different levels of phytase enzyme added and soybean meal containing feed in their study. At the end of the study, they reported that the FCR and PER were improved and the SGR did not change to this was not statistically significant. Xu et al. (2020) conducted a study on juvenile hybrid sturgeon (Acipenser baerii $q \times$ Acipenser schrenckii $\widehat{\delta}$ ) for 12 weeks. In their study, they created four feed groups (FM 100, FM 100p, FM 250, and FM 250p), which contains 10\% and 25\% fishmeal and the other protein source (soybean meal, wheat flour, cottonseed protein), with the same proportions phytase supplemented or without. As a result, they reported that there was no significant difference between SGR, WGR, FI, and FCR. Maas et al. (2018) conducted a study on the effect of phytase, xylanase, and their combination on growth performance and nutrient utilization in Nile tilapia (O. niloticus). At the end of the study, it was reported that both phytase and xylanase-supported feed groups significantly affected growth. It was stated that growth was similar to control in xylanase-supplemented diets, whereas growth in phytase-supplemented diets improved. Also, the best growth performance was determined with fish fed the diet supplemented with both phytase and xylanase groups. Ayhan et al. (2008) investigated the effects of protease, multienzyme, and phytase additions on growth, feed evaluation and nitrogen-phosphorus excretion in sea bream feeds using soybean meal instead of fishmeal. At the end of the study, there was no significant difference between the groups in terms of WG and the SGR, while the phytase-added group has been reported to have significantly better FCR compared to the control group. As a result of this study, WG, SGR, FCR, PER, and CF were positively affected in all groups in parallel with the increase in enzyme amount in fish fed with Siberian sturgeon feed supplemented with phytase enzyme and hazelnut meal. The best group was identified as G4, which has been fed with feed supplemented with $1.00 \mathrm{~g} \mathrm{~kg}^{-1}$ phytase, and the G4 group was found to be statistically significant compared to all groups (P<0.05). In the present study, the inclusion of phytase enzyme in fish feed has improved the rate of utilization of hazelnut meal additive. This study is similar to those studies of Lin et al. (2007), Ghomi et al. (2012), Ávila et al. (2015), Maas et al. (2018), Chen et al. (2019), and Xu et al. (2020) the group FM 100p in terms of WG and SGR and FM 250p in terms of FI and FCR in which the enzyme supplement had a positive effect on the growth parameters. However, the current study is different from the studies of Wang et al. (2009) who have reported that SGR, FCR, and PER are not statistically different. Also, this study is different from the studies of Ayhan et al. (2008) in terms of SGR, Yan et al. (2002) in terms of WG and Xu et al. (2020) the group FM 100p in terms of FI and FCR and FM 250p in terms of WG and FI. It is thought that the difference between the results can be due to the different fish species used, different raw materials of plant origin, the enzyme used in a different amount of use.

The effect of apparent phosphorus digestibility is one of the most important criteria to evaluate the effect of phytase on phosphorus digestibility. Phytase helps to prevent phosphorus contamination by converting the phosphate in the form of phytate into usable phosphorus and enables the use of phosphorus in a more convenient way, reducing inorganic phosphate supplementation in the feed (Selle et al. 2000; Cao et al. 2007; Mireles-Arriaga et al. 2015). Phytate degrading enzymes are recommended to increase the nutritional value of plant material. In recent years, to reduce phosphorus pollution as an environmental waste in intensive animal husbandry, the use of phytase enzyme in animal feed has been brought to the agenda (Asan 2007). In the present study, the effect of phytase enzyme on growth parameters and digestibility has been investigated by participating in different proportions to feed with containing 30\% hazelnut meal. The best total digestion rate was observed in the G4 group where the most phytase enzyme was added with $77.14 \%$. Rodehutscord \& Pfeffer (1995) added 1000 IU kg-1 phytase enzyme to trout feed containing soybean meal and reported that phosphorus digestibility increased from $25 \%$ to $57 \%$ at $15^{\circ} \mathrm{C}$ by adding phytase to the diet. In another study, protease, different enzyme mixtures, and phytase enzymes were added separately to sea bream fish feeds containing fish meal and soybean meal, and their effects on growth parameters and nitrogenphosphorus pollution were investigated. As a result, it was reported that the best phosphorus digestibility was determined in the phytase supplemented feed group (Ayhan et al. 2008). Wang et al. (2009) conducted a digestibility study with soybean meal containing phytase enzyme supplementation in rainbow trout. They reported that with phytase supplementation, the apparent digestibility coefficient (ADC) of diet protein and minerals was increased, also as a negative effect of phytase on the ADC of lipid. Also, they stated that with phytase supplementation, lipid excretion slightly increased, but nutrient excretion decreased in feces. Xu et al. (2019) reported that the phytase-supplemented FM 100p group showed better ADC than the phytase-free FM 100 group, while the phytase-supplement FM 250p group showed a worse ADC value than the phytase-free FM 250. As the reason for this, it was reported that the plant protein level in the FM 250p diet does not provide sufficient phytate-P and phytate complexing protein, also, the ability of fish to digest and absorb fish meal-rich bone phosphorus be insufficient. Maas et al. (2018) reported that the phytase supplement increased ADC from $90.1 \%$ to $91.2 \%$ for crude protein, $92.9 \%$ to $93.9 \%$ for crude lipid, and $49.7 \%$ to $56.7 \%$ for carbohydrates.

The improvement of the growth performance in fish and well assessment of feed, thus reduction of environmental waste most likely related to the digestibility of nutrients. Similarly, in this study, enzyme use in fish feeds improved growth performance and feed conversion ratio. These observations support the knowledge that phosphorus can be used more conveniently by degrading phytate phosphorus in feeds supplemented by the phytase enzyme. It has been concluded that the use of phytase may contribute to environmental sustainability in connection with less waste release to the receiving environment.

Farhangi \& Carter (2007) have added 4 different exogenous enzymes to peeled lupin containing (Lupinus albus) feed of the rainbow trout $(16.58 \mathrm{~g})$ and they reported no statistically significant change in WG and carcass composition between the groups at the end of a 6-week feeding trial. Imanpoor \& Bagheri (2012), in their study on Iranian sturgeon (352.07 g) (Acipenser persicus) added $0.5 \mathrm{~g} \mathrm{~kg}^{-1}$ magnesium and $0.5 \mathrm{~g} \mathrm{~kg}^{-1}$ phytase enzyme to the soybean meal supplement and they reported that HSI values were better in enzyme-supplemented groups compared to the control group but there was no difference in body 
composition values. Biswas et al. (2019) prepared two different feeds and added phytase enzyme in the second feed trial. They reported that phytase enzyme addition did not make a significant difference on VSI, HSI, crude protein, and crude lipid compared to the control groups and that the groups differed only with the feed group that they prepared with a protein-based diet. In this study with the Siberian sturgeon fed with $30 \%$ containing hazelnut meal, a significant difference was detected between the G1 and the G4 group in HSI, VSI, crude protein, and crude lipid ratios depending on the amount of enzyme addition. The findings are similar to the studies of Lin et al. (2007) who used mixed enzyme supplemented in hybrid tilapia (Oreochromis niloticus $\mathrm{x}$ O. aureus). In terms of body composition, this study is similar to studies of Farhangi \& Carter (2007), Imanpoor \& Bagheri (2012), and Biswas et al. (2019) in some aspects, but is also different in other aspects. It is thought that this difference may be since fish species and weights are different, the sources of plant protein used are different, the amounts of enzymes are different and the studies have been conducted under different environmental conditions.

As a result, the addition of $1 \mathrm{~g} \mathrm{~kg}^{-1}$ of phytase enzyme to the Siberian sturgeon diet with $30 \%$ hazelnut meal did not have a negative effect on WG, FCR, PER, CF, nutrient digestion rate, and body composition. The addition of $1 \mathrm{~g} \mathrm{~kg}^{-1}$ phytase enzyme in Siberian sturgeon (mean $960.23 \pm 0.55 \mathrm{~g}$ ) feed with $30 \%$ containing hazelnut meal had a positive effect on FCR. Also, the FCR and PER were in harmony with each other. Thus, it is understood that the feed supplemented with phytase enzyme and containing hazelnut meal is better evaluated by the Siberian sturgeon. It is concluded that the addition of phytase will contribute to the interaction of aquaculture and a sustainable environment by decreasing phosphorus excretion by defecation as it will increase the digestibility of phosphorus by degrading phytate in plant feed additives.

\section{Acknowledgments}

This investigation was supported with the project number "2015.53001.103.02.03” by Recep Tayyip Erdogan University Scientific Research Projects Unit. The authors acknowledge special thanks to all the project team and the Scientific Research Unit of the University for their support and effort. The authors are very grateful to Dr. Munevver ORAL for her contribution.

\section{References}

Akiyama T (1995). Nutritive value of alternative protein sources. In: New Feeds for Fish Culture Utilization of Alternative Protein Sources, Suisangaku Series 102, Koseisha-koseikaku, Tokyo pp. 35-42

Anonymous (2017). Fisheries Statistics. TUIK, Retrieved in December 20, 2019, from www.tuik.gov.tr

Arıman Karabulut H \& Osmanoglu M I (2019). The investigation possibilities of using whiting meal instead of pelagic fish meal in Russian sturgeon (Acipenser gueldenstaedtii Brandt, 1833) diet. Fresenius Environmental Bulletin 28(6): 4935-4948

Arıman Karabulut H, Kurtoğlu İ Z \& Kırtan Y E (2019). Effects of the Feeds Containing Hazelnut Meal as Plant Protein Source on Growth Performance and Body Composition of Siberian sturgeon (Acipenser baerii) and Economic Profitability Value. Turkish Journal of Veterinary and Animal Sciences 43(2): 244-252 https://doi.org/10.3906/vet-1807-7

Association of Analytical Communities (AOAC) (2000). Official Methods of Analysis, $19^{\text {th }}$ ed. Arlington, Virginia, USA

Asan M (2007). Microbial phytases, applications and biotechnology. Tarım Bilimleri Dergisi-Journal of Agricultural Sciences 13(2): 147-155 https://doi.org/10.1501/Tarimbil_0000000438

Ávila D S, Sánchez E A, Hernández L H H, Araiza M A F \& López O A (2015). Addition of yeast and/or phytase to diets with soybean meal as main protein source: Effects on growth, P excretion and lysozyme activity in juvenile rainbow trout (Oncorhynchus mykiss Walbaum). Turkish Journal of Fisheries and Aquatic Sciences 15: 215-222 https://doi.org/10.12714/egejfas.2017.34.1.05

Ayhan V, Diler I, Arabaci M \& Sevgili H (2008). Enzyme supplementation to soybean based diet in Gilthead Sea Bream (Sparus aurata): Effects on growth parameters and nitrogen and phosphorus excretion. Kafkas Üniversitesi Veteriner Fakültesi Dergisi 14(2): 161-168 https://doi.org/10.9775/kvfd.2008.33-a

Biswas A, Araki H, Sakata T, Nakamori T \& Takiia K (2019). Optimum fish meal replacement by soybean protein concentrate from soybean milk and phytase supplementation in diet of red sea bream, Pagrus major. Aquaculture 506: 51-59 https://doi.org/10.1016/j.aquaculture.2019.03.023

Cao L, Wang W, Yang C, Yang Y, Diana J, Yakupitiyage A, Luo Z \& Li D (2007). Application of microbial phytase in fish feed. Enzyme and Microbial Technology 40(4): 497-507 https://doi.org/10.1016/j.enzmictec.2007.01.007

Chen A, Liu X, Cui C, Yang C, Wang Y, Bu X \& Yang Y (2019). An evaluation of phytase for Channel catfish (Ictalurus punctatus) fed all plant - protein diet: Growth performance, nutrient utilization and P equivalency value. Aquaculture Nutrition 25(1): 215-224 https://doi.org/10.1111/anu.12845

Farhangi M \& Carter C G (2007). Effect of enzyme supplementation to dehulled lupin-based diets on growth, feed efficiency, nutrient digestibility and carcass composition of rainbow trout, Oncorhynchus mykiss (Walbaum). Aquaculture Research 38: 1274-1282 https://doi.org/10.1111/j.1365-2109.2007.01789.x

Furukawa A \& Tsukahara H (1966). On the acid digestion method for the determination of chromic oxide as an index substance in the study of digestibility of fish feed. Bulletin of the Japanese Society of Scientific Fisheries 32: 502-506. https://doi.org/10.2331/suisan.32.502

Ghomi M R, Shahriari R, Langroudi H F, Nikoo M \& von Elert E (2012). Effects of exogenous dietary enzyme on growth, body composition, and fatty acid profiles of cultured great sturgeon Huso huso fingerlings. Aquaculture international 20(2): 249-254 https://doi.org/10.1007/s10499-011-9453-9

Gimenez A V F, Diaz A C, Velurtas S M \& Fenucci J L (2009). Partial substitution of fishmeal by meat and bone meal, soybean meal, and squid concentrate in feeds for the prawn, Artemesia longinaris: Effect on Digestive Proteinases. The Israeli Journal of Aquaculture Bamidgeh 61(1): 48-56 https://doi.org/10.46989/001c.20546

Imanpoor M R \& Bagheri T (2012). Effects of replacing fish meal by soybean meal along with supplementing phosphorus and magnesium in diet on growth performance of Persian sturgeon, Acipenser persicus. Fish Physiology and Biochemistry 38(2): 521-528 https://doi.org/10.1007/s10695-011-9532-x 
Jiang H B, Chen L Q \& Qin J G (2018). Fishmeal replacement by soybean, rapeseed and cottonseed meals in hybrid sturgeon Acipenser baerii + A Acipenser schrenckii $\hat{\jmath}$. Aquacult Nutrition 24(4): 1369-1377 https://doi.org/10.1111/anu.12674

Lin S, Mai K \& Tan B (2007). Effects of exogenous enzyme supplementation in diets on growth and feed utilization in tilapia, Oreochromis niloticus $\times$ O. aureus. Aquaculture research 38(15): 1645-1653 https://doi.org/10.1111/j.1365-2109.2007.01825.x

Liu H, Wu X, Zhao W, Xue M, Guo L, Zheng Y H \& Yu Y (2009). Nutrients apparent digestibility coefficients of selected protein sources for juvenile Siberian sturgeon (Acipenser baerii Brandt) compared by two chromic oxide analyses methods. Aquaculture Nutrition 15: 650-656 https://doi.org/10.1111/j.1365-2095.2008.00634.x

Lovell T (1981). Laboratory Manual for Fish Feed Analysis and Fish Nutrition Studies. Department af Fisheries and Allied Aquacultures International Center for Aquaculture, Auburn University, US 65 pp

Maas R M, Verdegem M C J, Dersjant-Lib Y \& Schrama J W (2018). The effect of phytase, xylanase and their combination on growth performance and nutrient utilization in Nile tilapia. Aquaculture 487: 7-14 https://doi.org/10.1016/j.aquaculture.2017.12.040

Mireles-Arriaga A I, Espinosa-Ayala E, Hernández-García P A \& Márquez-Molina O (2015). Use of exogenous enzyme in animal feed. Life Science Journal 12(2): 23-32

Morales G A, Denstadli V, Collins S A, Mydland L T, Moyano F J \& Øverland M (2016). Phytase and sodium diformate supplementation in a plant-based diet improves protein and mineral utilization in rainbow trout (Oncorhynchus mykiss). Aquaculture Nutrition 22(6): 13011311 https://doi.org/10.1111/anu.12340

Omnes M H, Le Goasduff J, Le Delliou H, Le Bayon N, Quazuguel P \& Robin J H (2017). Effects of dietary tannin on growth, feed utilization and digestibility, and carcass composition in juvenile European seabass (Dicentrarchus labrax L.). Aquaculture Reports 6: 21-27 https://doi.org/10.1016/j.aqrep.2017.01.004

Rodehutscord M \& Pfeffer E (1995). Effects of supplemental microbial phytase on phosphorus digestibility and utilization in rainbow trout (Oncorhynchus mykiss). Water Science and technology 31(10): 143-147 https://doi.org/10.2166/wst.1995.0371

Schlemmer U, Frølich W, Prieto R M \& Grases F (2009). Phytate in foods and significance for humans: food sources, intake, processing, bioavailability, protective role and analysis. Molecular nutrition and food research 53: 330-375 https://doi.org/10.1002/mnfr.200900099

Selle P H, Ravindran V, Caldwell R A \& Bryden W L (2000). Phytate and phytase: Consequences for protein utilisation. Nutrition Research Reviews 13: 255-278 https://doi.org/10.1079/095442200108729098

von Danwitz A, van Bussel C G, Klatt, S F \& Schulz C (2016). Dietary phytase supplementation in rapeseed protein based diets influences growth performance, digestibility and nutrient utilisation in turbot (Psetta maxima L.). Aquaculture 450: 405-411 https://doi.org/10.1016/j.aquaculture.2015.07.026

Wang F, Yang Y, Han Z, Dong H, Yang C \& Zou Z (2009). Effects of phytase pretreatment of soybean meal and phytase-sprayed in diets on growth, apparent digestibility coefficient and nutrient excretion of rainbow trout (Oncorhynchus mykiss Walbaum). Aquaculture International 17(2):143-157 https://doi.org/10.1007/s10499-008-9187-5

Xu G-L, Xing W, Li T-L, Ma Z-H, Jiang N, Xu S-D, Xu M, Yu H-H \& Luo L (2020). The effects of different fishmeal level diets with or without phytase supplementation on growth performance, body composition, digestibility, immunological and biochemical parameters of juvenile hybrid sturgeon (Acipenser baerii Brandt 우 $\times$ A. schrenckii Brandt $\sigma^{7}$ ). Aquaculture Nutrition 26: 261-274 https://doi.org/10.1111/anu.12987

Yan W, Reigh R C \& Xu Z (2002). Effects of fungal phytase on utilization of dietary protein and minerals, and dephosphorylation of phytic acid in the alimentary tract of channel catfish Ictalurus punctatus fed an all-plant-protein diet. Journal of the World Aquaculture Society 33(1): 10-22 https://doi.org/10.1111/j.1749-7345.2002.tb00473.x

Yeşilayer N, Kaymak I E, Gören H M \& Karslı Z (2013). Alternative uses of plant protein sources to fish meal in fish feed. Gaziosmanpaşa Journal of Scientific Research 4: 12-30

Yiğit N Ö, \& Koca S B (2011). The use of enzyme in fish feeds. Journal of Fisheries Sciences 5(3): 205-212

Zhu Y, Qiu X, Ding Q, Duan M \& Wang C (2014). Combined effects of dietary phytase and organic acid on growth and phosphorus utilization of juvenile yellow catfish Pelteobagrus fulvidraco. Aquaculture 430: 1-8 https://doi.org/10.1016/j.aquaculture.2014.03.023

(C) 2021 by the authors. Licensee Ankara University, Faculty of Agriculture, Ankara, Turkey. This article is an open access article distributed under the terms and conditions of the Creative Commons Attribution (CC BY) license (http://creativecommons.org/licenses/by/4.0/). 